\title{
Naval Officer as a Leading Personality: Strategic Approach and Challenges
}

\author{
S. Lileikis \& P. Dukel \\ Lithuanian Maritime Academy, Klaipeda, Lithuania
}

\begin{abstract}
The aim of this article is to consider a naval officer as a leading personality from a strategic point of view in respect of the challenges and opportunities of professional development, by characterizing the needs and changes of the naval officers' profession and discussing the transition period for the training of Lithuanian naval officers. The main methods applied to the research are scientific literature analysis, document analysis, interpretation, and synthesis. The basic methodological principles of the research are as follows: humanism, personalism, and cognitive psychology. The type of the research is a descriptive study. The changes, such as the absence of a clear border between the front line of action and the back area, expression of war as a changing and, at the same time, constant process, as well as changes in the social environment of the officer's profession, when the challenges are not always purely physically military in nature but also diplomatic and psychological, require a high level of military training of naval officers. Taking into account the transition period for the training of Lithuanian naval officers at non-foreign military academies, their professional training should be strengthened by collaboration with the Alliance's partners, by updating existing training programs and coordinating them with Western military academies, which have a long tradition of training naval officers depending on the relevant geopolitical challenges and potential threats, as well as technological and social changes.
\end{abstract}

\section{INTRODUCTION}

\subsection{Relevance of the research problem}

The special geopolitical situation of Eastern Europe from a security point of view determines the need to be ready for joint defense having a strong and motivated army composed of members each of whom is a personality as a totality of all personal qualities that define its place in the military community. In general, personality is defined by humanistic ideals, purposeful decision-making, quick thinking, ability to work in a team, knowledge and application of military equipment and technology. More specifically, all this is defined by appropriate personal, social, and subject competences. The Eastern shore of the Baltic Sea is currently a field of tension caused by information war in terms of threats from the East, which poses a real danger of potential war. Lithuania, Latvia, and Estonia are members of the North Atlantic Treaty Organization (NATO), however, they are in a special military threat zone of their eastern neighbor.

On the one hand, being a member of NATO is a great achievement for these countries because NATO's purpose is to guarantee the freedom and security of its members through political and military means. Political means are understood in the following way: NATO promotes democratic values 
and enables its members to consult and cooperate on defence and security-related issues to solve problems, build trust and, in the long run, prevent conflict. Military means are as follows: NATO is committed to the peaceful resolution of disputes. If diplomatic efforts fail, it has the military power to undertake crisis-management operations. These are carried out under the collective defence clause of NATO's founding treaty - Article 5 of the Washington Treaty or under a United Nations mandate, alone or in cooperation with other countries and international organizations [13].

On the other hand, it is very likely that during a possible military conflict the local Naval Forces will carry out tasks at the initial phase without the full support of the Allies. Thus, they must be able to plan and carry out tasks independently, and only naval officers with a high level of motivation (in the broad sense) can plan and lead.

Paying attention to the Republic of Lithuania, represented by the authors of this article, it must be said that the territorial sea of Lithuania, the exclusive economic zone, and Klaipeda State Seaport are critical territories for Lithuania. The capacity of the port allows to quickly and efficiently provide foreign soldiers with all the necessary means in the country. In order to ensure the safe arrival of the Allies by sea, it is important to develop and maintain a high level of the Naval Flotilla and preparedness for immediate response to possible disruptions of commercial shipping and illegal border crossing of the Republic of Lithuania.

However, after the Republic of Lithuania became a member of NATO, it faced with an important challenge - the Lithuanian Naval Forces lost the opportunity to train its officers in Western European naval academies. As a result, this period has reduced the scope of proper preparation for equal participation in international exercises and operations with Allies, and above all, the scope of development of the qualities and values of a leader and provision of future officers with the theoretical knowledge and practical skills necessary to lead a combat unit.

The problems of professional training of officers, taking into account the professional development of the officer's personality, are examined in various scientific aspects, especially from a point of view of ideology, axiology, leadership, technology, education, (self-) development of personality, psychological resilience, and motivation [1-5; 7-8; 10; 12; 15-17; 19-23]. The issues of organizing professional training for naval officers and for a naval officer as a personality have been only recently scientifically addressed by strategically assessing the Lithuanian military study system.

\subsection{Methodology of the research}

The object of the research is a naval officer as a leading personality.

The subject of the research is the challenges of the naval officer's development.

The aim of the article is to consider a naval officer as a leading personality from a strategic point of view in respect of the challenges and opportunities of professional development.

The tasks of the research are as follows:

1 To characterize the needs and changes of the naval officers' profession.

2 To discuss the transition period for training Lithuanian naval officers.

The main methods applied to the research are scientific literature analysis, document analysis, interpretation, and synthesis.

The basic methodological principles of the research are as follows:

- Humanism, which is an anthropocentric worldview that considers the human being as the highest value on planet Earth; the value of an individual embodies the meaning of educating him/her by enabling him/her to express himself/herself freely and responsibly in a society; this worldview is a basis for a free personal decision to become a naval officer after receiving responsible professional training;

- Personalism sees a human being as a personality in an ontological sense with an emphasis on the uniqueness, self-awareness, and free will of each person; this attitude is the basis for individualized training, as well as for self-training in respect of gaining motivation and preparing for the naval officer's professional life;

- Cognitive psychology highlights the possibilities of personal consciousness and cognition by making the directions of personal selfdevelopment and person's professional expression relevant, meaningful and changeable; cognitive psychology methodologically bases a possibility for professional education and training of naval officers and purposeful organization thereof.

The type of the research is a descriptive study.

\section{RESULTS OF THE RESEARCH}

\subsection{Needs and changes of the naval officers' profession}

The modern environment of military operations is characterized by the absence of a clear border between the front line of action and the back area. This result in uncertain, ambiguous, complex, volatile, and frequently changing situations and environment in which a soldier or military unit has to operate.

In addition, the social environment of the profession of a soldier, and especially an officer has changed. The nature of the problems and challenges faced by the army and its leadership is not exclusively physically military. More and more often, in certain specific situations, an officer must act not only as a "soldier-specialist", but also as a critically thinking "soldier-citizen", as well as "soldier-diplomat". In this context, the officer's studies and military training must be focused on the officer's ability to understand changes in the environment and adequately assess them in order to solve the relevant problem or challenge in a rational and effective way. 
The training of officers should be focused on flexibility, their thinking should be based on the selection of alternative methods and means (variants of actions), which should be used to influence the military, conceptual, moral, and psychological power of enemies, by attacking them under favorable conditions. This allows to achieve the best battle results with fewer resources - so that smaller forces could suppress larger ones.

Of course, at a household level, a stereotype has emerged that soldiers are actors who carry out orders rather than ask questions. Someone would say that war is such a practical and dynamic thing that it makes no sense to spend time thinking about the war; when bullets are buzzing around, there is no time to flip through the books and look in them for answers how to beat the enemy; a soldier or officer asking many questions can become a heavy burden or even an obstacle to achieving the goals set.

However, it is difficult to agree with such a position, given what a truly dynamic process war is. War is a changing and, at the same time, constant phenomenon. In order to understand the interaction between these two elements, it is important to constantly research and reflect on the real image of war and its departure from the ideal image. Since the restoration of independence, Lithuanian soldiers have participated in many international missions in Bosnia, Kosovo, Iraq, Afghanistan, off the coast of Somalia, and in Mali. What principles and ideas were used to prepare for these missions? Why were some ideas or military doctrines used while others not? Why were the conceptual principles offered by certain countries used? Why is the content of the Lithuanian military doctrine and other similar documents the way it is? What is the origin of ideas reflected therein? Some of the answers are already known. Many best practices have been adopted from Allies in the West.

The training of officers is a tradition of the British military thought adopted by NATO. The military in Lithuania has been newly created. The best western tradition and models have been adopted and applied. Thus, in fact, we can tell our colleagues abroad about the effectiveness of the models they have developed [16].

The crisis in Ukraine and the aggressive foreign policy of the Russian Federation has changed the stagnant attitude of politicians towards national defense both in Lithuania and in the international arena and has led to increased appropriations in this area [4]. The agreement of the political parties to fulfill the commitments made by the NATO Alliance on defense financing has stimulated the processes of modernization of the army that has been underway since 2016 and has received a great deal of public attention and discussion about the validity of one or another purchase in light of existing geopolitical situation. The problem becomes deeper when the people involved focus on the acquisition of new equipment, and the importance of training a qualified commander seems to be forgotten. The regulated responsibility of Naval Forces is the training of personnel as a key and critical resource. Without a properly trained naval officer, the most advanced technology is worthless.
The army is a hierarchical organization based on discipline, patriotism, national and military values. Its units must be headed by officers who are besttrained leaders, who know how to point in the necessary direction, explain the goal, clearly define tasks, and who are able to persuade and motivate. The main values and qualities of a naval officer are patriotism, loyalty, commitment, honesty, courage, respect, honor, and extensive professional knowledge related to the old maritime traditions, high culture of communication, and opportunities to participate in international exercises in both hemispheres of the Earth. The naval officer is a leading personality precisely in terms of these values and qualities.

In his article "Separate but Equal - a Look at Officer Training in the U.S. Navy and Merchant Marine" [6], John Hafner notes that a destroyer and a tanker is based on the same principle of being on the water, however, the internal organization, purpose, specificity, preparation, and responsibility covered by the ships are separated by an invisible border. Unlike a merchant fleet, the main goal of the U.S. Navy is to prepare an officer according to his/her competencies and professional knowledge for him/her to become optimally suited for service both onboard and ashore. Considering the wide range of professional knowledge required, U.S. naval officers are rotating their line of service from direct command of the ship's crew to the operational and strategic planning sector ashore, gradually moving up the career ladder. A warship is one of the most complicated ships in terms of construction and specifics.

Therefore, the commander of the ship is not required to take care of the propeller rotation. He/she is responsible for the proper management of the crew (specialists), its motivation, appropriate decisionmaking in an emergency situation, and successful completion of a tactical or operational task.

Warfare is one of the most complex activities. Soldiers often have to deal with very difficult conditions, which pose a threat to their lives and health, endure heavy physical exertion, and experience various psychological and spiritual shocks and challenges. Naval officers must be particularly prepared well to operate in critical conditions because the mental state, behavior, and combativeness of soldiers depend on the psychological condition of the officers. An officer is required to have a clear and strong civic and moral position and to know his/her professional field well [15].

For a naval officer to be well-prepared, it is necessary to organize his/her personal strategic selfdevelopment based on a comprehensive approach to his/her personality. The main areas of organization of the strategic self-development of the naval officer in accordance with his/her personality levels, i.e. physical, psychological, and spiritual, are presented in Table 1. 
Table 1. Organization of strategic self-development of naval officers

\begin{tabular}{lccc}
\hline MAIN AREAS & \multicolumn{3}{c}{ PERSONALITY LEVELS } \\
& Physical & Mental & Spiritual \\
\hline 1 Moral position & & + & + \\
2 Flexible thinking & & + & + \\
3 Physical / mental health & + & + & + \\
4 Education / training & + & + & + \\
5 Wide subject knowledge & + & + & \\
6 Psychological resilience & + & + & + \\
\hline
\end{tabular}

The personal strategic self-development of naval officers, including all aforementioned personality levels, can deliver the expected results related to the challenges of military activities.

British historian David G. Morgan-Owen notes in his article "Approaching a Fork in the Road: Professional Education and Military Learning" [11] that currently in light of the geopolitical situation military service is gaining routine functions, and the curriculum in academies often stagnates. It is appropriate to highlight that science, as well as knowledge, is a changing and dynamic process that must evolve and change along with the environment. Recently, the ranks of military academies have been supplemented by young people focused on science; nevertheless, they are far from warfare and physical discipline. Of course, on the one hand, it is important to take into account the need for cadets to link their future plans to the civilian sector, if necessary. On the other hand, we should not forget about the natural purpose of a military academy - to train patriotic, strong-willed, and psychologically strong officers as leaders of the future, based on the lessons learned in the past.

\subsection{Transition period for the training of Lithuanian naval officers}

In 1991, Order No. 352 of the Minister of National Defense of the Republic of Lithuania "On the formation of a Coast Guard Team of the Border Guard Service" legalized the subordination of the Naval Forces to the Border Guard Service. An Expert Council was set up, and one of its tasks was to create a System for training personnel for Naval Forces (which is still in operation) and submit it to the Ministry of National Defense. According to this system, specialists are trained at Kaunas University of Technology and Klaipeda University. Military education and officers' degrees are awarded after receiving additional training in Lithuanian or foreign military academies [9].

In 1992-2014, the Lithuanian Naval Forces had the opportunity to train its naval officers at foreign military academies in Western Europe (Sweden, Norway, Germany, and Denmark) and the USA based on the NATO Partnership for Peace program. The Partnership for Peace is a program of practical bilateral cooperation between individual EuroAtlantic partner countries and NATO. It allows partners to build up an individual relationship with NATO and choose their own priorities for cooperation. All European nations that participate in the North Atlantic Cooperation Council and those that take part in the Organization for Security and Co-operation in Europe and wanted to cooperate with NATO were invited to join the Partnership for Peace program. The goal of the Partnership for Peace program is to strengthen stability and security across Europe. The invitation to participate in the program was accepted by 30 countries [14].

The strategic objective of the program is to support the member states in rebuilding their armed forces and preparing qualified command personnel for service, including the newly formed Naval Forces. The following NATO members have offered their support in training naval officers for the Lithuanian Naval Forces: the USA with a successful U.S. Naval Academy in Annapolis (its activity is based on the motto "From Knowledge, Seapower"), Norway, Germany, and Denmark, represented by the Royal Danish Naval Academy, which has developed the oldest European model for training naval officers, and Sweden, which is neutral towards NATO. In addition, allied naval partners have closely worked with the Lithuanian Naval Forces by training Lithuanian naval officers, actively supporting warship acquisition projects, and leading major exercises in the Baltic Sea, e.g., "Northern Coasts", "Baltops", etc., in which the warships of the Lithuanian Naval Forces have been successfully participating for many years [18].

In 2004, the Republic of Lithuania became a member of NATO, and because of that, the Lithuanian Naval Forces lost the opportunity to train its officers in Western European naval academies. As a result, the current transition period of the Naval Forces has reduced the scope of not only the adequate preparation for equal participation in international exercises and operations with Allies, but also the development of leadership qualities and values of the commander, which had been previously successfully developed at naval academies of Sweden, Norway, Denmark, Germany, and the USA. Several generations of naval officers for the Lithuanian Naval Forces were trained there.

In addition, Lithuanian naval officers notice that every year the number of junior officers is increased by insufficiently trained officers lacking the basics of naval warfare, and it is also questionable whether they would be able to respond adequately and responsibly during a military conflict or in an emergency situation in the context of the previouslymentioned changes in the social environment of the military profession and warfare in general.

Naval officers are trained for the Lithuanian Naval Forces in accordance with the Order No. V-1229 of the Commander of the Lithuanian Armed Forces issued in 2012 and its amendment No. V-64 issued in 2015. Instructors and professionals included in the junior officer commander training program of the Naval Forces organize military training of naval reserve officers, collaborating with the Lithuanian Maritime Academy where the training of naval officers for the Lithuanian Naval Forces has been organized since 1993.

The greatest burden of naval officer training falls on the Lithuanian Maritime Academy where students of the Lithuanian Military Academy can study under 
contract in order to prepare for work in the Naval Forces. These are academies having different purposes. The Lithuanian Military Academy is a university, and its officer training program is characterized by synergy, i.e. cadets are studying under the bachelor's study program and develop the qualities of a leader in parallel. The Lithuanian Military Academy is based on the science of warfare and pursues that the Lithuanian Armed Forces are characterized by the officers who are tactically and technically proficient, confident, and able to make appropriate decisions in critical circumstances. Students of the Lithuanian Military Academy, who have chosen maritime studies, can study at the Lithuanian Maritime Academy, which is a nonuniversity type of school focused on civil study programs, such as Marine Navigation, Marine Engineering, Marine Transport Logistics Technology, Port and Shipping Management, etc. Students of the Lithuanian Maritime Academy have an opportunity to participate in the junior officer commander training.

In accordance with the Order No. V-64 of the Commander of the Lithuanian Armed Forces issued in 2015, persons who wish to participate in the junior officer commander training must have expressed a wish to participate in the training in writing and be suitable for the training in accordance with the procedures established by law. The staff of the junior officer commander training organizes the selection of candidates for the training in cooperation with the National Defense Volunteer Force.

The main purpose of the junior officer commander training is to provide future reserve officers with the theoretical knowledge and practical skills necessary to lead the combat unit. However, the junior officer commander training program of Naval Forces is based on the principle of training a land reserve officer in accordance with the subjects taught, such as tactics, weapons, shooting, military engineering, communications, and military topography.

The Lithuanian Maritime Academy is training leading seafarers, i.e. marine navigators, marine engineers, and marine electrical and electronic engineers, in accordance with the conventions of the International Maritime Organization and the International Standard for Qualifications. As it has been mentioned, the junior officer commander training organized at the Lithuanian Maritime Academy acts as an additional choice of the students who, being participants of the junior officer commander training, can study only introductory warfare subjects. In addition, if they complete the junior officer commander training successfully, they rarely associate their professional future with the Naval Forces.

The requirements established for naval officers are very high. The Order No. V-91of the Commander of the Lithuanian Naval Forces issued in 2017 indicates that a commander of a combat unit performs the duties of the officer in charge of a navigational watch and must be able to direct all operations of the ship, e.g., naval activities related to a helicopter, perform tactical maneuvering in a combination of ships, make a recognized maritime picture, etc. in accordance with the procedures approved by NATO.
Therefore, it can be assumed that future commanders of combat units cannot be optimally prepared for the duties of a watch officer without the preparation that includs at least the completion of the course that usually forms the core of introductory programs of foreign military academies, including comprehensive training covering the needs of modern warfare. A strategic decision on more effective training of Lithuanian naval officers in such a transition period should integrate comprehensive training, by defining how to strengthen the connection between their preparation and the Alliance's partners (Table 2).

Table 2. Optimal training of naval officers

\begin{tabular}{l} 
COLLABORATION WITH THE ALLIANCE'S PARTNERS \\
1 Updating existing training programs \\
2 Coordinating them with Western military academies \\
3 Providing the possibility of joint programs \\
\hline
\end{tabular}

The above headlines and greater diversity with a more flexible approach to the professional training of naval officers would help to ensure optimal training in light of the current Lithuanian context.

\section{CONCLUSIONS}

In summarizing the problematical analysis of a naval officer as a leading personality from a strategic point of view, it can be stated that:

- The changes, such as the absence of a clear border between the front line of action and the back area, expression of war as a changing and, at the same time, constant process, and changes in the social environment of the officer profession, when the challenges are not always purely physically military in nature but also diplomatic and psychological, require a high level of military training for naval officers, who must be in a proper moral and civic position, have a wide range of specific knowledge, and be characterized by critical and flexible thinking, anticipation of alternative options, understanding of changes in the social environment, and appropriate response to them;

- Considering the transition period for the training of Lithuanian naval officers at non-foreign military academies, their professional training in light of the aforementioned problems, changes, and needs, should be strengthened by collaboration with the Alliance's partners, by updating existing training programs and coordinating them with Western military academies, which have a long tradition of training naval officers. It is appropriate to provide the possibility of joint programs in order to adequately participate in joint exercises with Alliance's partners in the Baltic Sea. 


\section{REFERENCES}

[1] Bohnert M. Innere Führung auf dem Prüfstand. Norderstedt: Books on Demand, 2017.

[2] Bouchard J. Think like a Black Belt. New York: San Chi Publishing, 2010.

[3] Brake T. Leadership development: learning from the U.S. Navy. Training, Vol. 55, No. 3, pp. 20-21, 2018.

[4] Dykyi E. Hibridinis Rusijos karas: Ukrainos patirtis Baltijos šalims. Vilnius: Generolo Jono Žemaičio Lietuvos karo akademija, 2016.

[5] Genzelis B., Žigaras F., Kazlauskaitè-Markelienè R., Petrauskaitè A. Šiuolaikinès visuomenès vertybinès orientacijos ir Lietuvos kariuomene. Vilnius: Generolo Jono Žemaičio Lietuvos karo akademija, 2008.

[6] Hafner J. Separate but equal - a Look at Officer training in The U.S. Navy and Merchant Marine. gCaptain, https://gcaptain.com, 2017.

[7] Hammouti-Reinke N. Ich diene Deutschland: Ein Plädoyer für die Bundeswehr - und warum sie sich ändern muss. Hamburg: Rowohlt, 2019.

[8] Kanapeckaitè R. Psichologinio atsparumo ugdymas rengiant karininkus. Šiuolaikinès visuomenès ugdymo veiksniai, Vol. 3, pp. 183-191, 2018.

[9] Kažerskas R., Brencius A., Vitkauskas A. Karinès jūru pajègos: 1990/1991 metai. Kariniu jūru pajëgu istorijos metraštis, pp. 19-23, 2012.

[10] Mcbride S. BRNC: A complete guide to preparation for Royal Naval Officer Training at Britannia Royal Naval College. Kent: How2become Ltd, 2016.

[11] Morgan-Owen D.G. Approaching a fork in the road: professional education and military learning. War on the Rocks, https://warontherocks.com, 2018.
[12] Neudeck G., Schröder H. Das kleine Buch von der Marine. Bremen: Maritime press, 2012.

[13] North Atlantic Treaty Organization. NATO Member Countries, https://www.nato.int, 2018.

[14] North Atlantic Treaty Organization. Partnership for Peace programme, https://www.nato.int, 2017.

[15] Puzinavičius B. Karininko asmenybès ugdymo ir saviugdos problemos tarpukario nepriklausomoje Lietuvoje. Karinis rengimas ir ugdymas Lietuvoje, pp. 130141, 2007.

[16] Šlekys D. Maslaus vyčio beieškant: lietuviškos karinès minties raida ir bükle po nepriklausomybès atkūrimo (19902014). Vilnius: Generolo Jono Žemaičio Lietuvos karo akademija, 2015.

[17] Trumpickienė M., Kalvaitienė G. Motyvacinės sistemos tęsti ar rinktis profesinę karo tarnybą Lietuvos kariuomenès karinėse jūrų pajègose tyrimas. Šiuolaikinès visuomenés ugdymo veiksniai, Vol. 4, pp. 125-141, 2019.

[18] U.S. Naval Forces Europe-Africa. Baltops, https://www.c6f.navy.mil, 2019.

[19] Vego M. Maritime Strategy and Sea Control. New York: Routledge, 2017.

[20] Vego M. Operational Warfare at Sea: Theory and Practice. New York: Routledge, 2017.

[21] Vileikienė E., Pocienè A., Aleknevičienè J. Motyvacija tarnauti Lietuvos kariuomenèje. Vilnius: Generolo Jono Zemaičio Lietuvos karo akademija, 2015.

[22] Willink J., Babin L. Extreme Ownership: How U.S. Navy SEALs Lead and Win. New York: St. Martin's Press, 2017.

[23] Žigaras F. Lietuvos kariuomenès karininku rengimo ir ju kvalifikacijos kèlimo raida (1990-2015). Šiuolaikinés visuomenés ugdymo veiksniai, Vol. 1, pp. 57-91. 